\title{
A MODEL OF SUCCESS FACTORS FOR E-GOVERNMENT ADOPTION - THE CASE OF POLAND
}

\author{
Ewa Ziemba, University of Economics in Katowice, Poland, ewa.ziemba@ue.katowice.pl \\ Tomasz Papaj, University of Economics in Katowice, Poland, tomasz.papaj@ue.katowice.pl \\ Rafat Żelazny, University of Economics in Katowice, Poland, rafal.zelazny@ue.katowice.pl
}

\begin{abstract}
This research focuses on the possible success factors of e-government in Poland. The purpose of this research was to identify success factors for adopting e-government in this country. The paper continues as follows. Firstly, the paper clarifies the concept of e-government and reviews success factors of e-government proposed by various authors in literature. Secondly, the success factors for adopting e-government in Poland are identified and the model of success factors is proposed. This model embraces the four categories of success factors. They are: economic, socio-cultural, technological and organizational. All the factors are considered in three stages: (1) ICTs access - reflecting technical and economic accessibilities of ICTs, (2) ICTs competences - reflecting competences and awareness related to the use of ICTs, (3) ICTs use - reflecting actual usage of ICTs. The paper concludes with a discussion on research findings, implications, and avenues for further research. This work contributes to extant research by showing a holistic approach to the success factors for adopting e-government, especially in transition economies.
\end{abstract}

Keywords: E-government, Critical Success Factors (CSFs), Information and Communication Technologies (ICTs)

\section{INTRODUCTION}

Creating the information society is an effective strategy to improve competitiveness of countries, regions, enterprises and citizens in the global market. Experts believe that information society is a key determinant of a country's growth e.g. economic growth, poverty reduction and sustainability $[8,32,57,12,70,85]$. The construction of information society is associated with a widespread use of information and communication technologies (ICTs) $[66,36,38,39,30,62]$. Furthermore, ICTs and information revolutionize the way of conducting business, work, study, and establishing relationships between government units, businesses (enterprises), and citizens at the same time $[10,13,14,15,16,31,37,47,82,72,80]$.

Nowadays the creation of information society has become a priority issue for the transition economies of Central and Eastern Europe. In general, the term transition economy refers to two groups of countries [41]. The first group comprises eight countries that joined the EU on 1 May 2004 (i.e. Czech Republic, Estonia, Hungary, Latvia, Lithuania, Poland, Slovakia, and Slovenia). Those countries are considered as leaders of the transition process. The second group consists of such countries as Belarus, Bulgaria, Croatia, Georgia, Moldova, Romania, Russia, Serbia, and Ukraine that are still transiting.

The information society is not possible without an effectively operating government and especially without an electronic government (e-government) [35, 42, 84]. E-government is one of several reforms undertaken by public administrations in order to increase the transparency and efficiency of government units and achieve significant cost reductions derived from the use of ICTs [33]. E-government is embedded in combinations of political conditions as well as cultural, technological and organizational changes designed to support and drive a profound transformation in government units [23]. It involves rethinking government organizations and processes, changing behavior, and using ICTs and information to make government services more efficient and easier to access for citizens, businesses and government units $[4,6,83]$.

The question asked in literature and practice is: why is the interest in e-government so high on the one hand, but its usage so low on the other $[49,28,2]$. The successful adoption of e-government means successful implementation of ICTs in government units and their successful usage by all government stakeholders, e.g. government employees, citizens and businesses. The adoption of e-government is not straightforward, it requires rather a complex technological, organizational, social, economic and political framework approach (undertaking) [61, 17, 11]. It 


\section{Issues in Information Systems \\ Volume 14, Issue 2, pp.87-100, 2013}

requires the coordination of many activities of government units and a close cooperation of employees, managers, IT specialists, as well as citizens and businesses. Additionally, there is a lack of proven scientific theories on and experience in the adoption of e-government in the transition economies of Central and Eastern Europe. Adoption of e-government in transition countries is not considered as successful as their counterparts in developed countries. Transition countries face challenges in making ICTs work over time and institutionalizing them in daily routines within their government units $[59,77,41]$. Among other things, it is very important to identify success factors for successful e-government adoption.

This research focuses on the possible success factors of e-government in Poland. The purpose of this research was to identify success factors for adopting e-government in Poland, which exemplify the "best practices" for the e-government, especially in transition economies in Europe. This paper is structured as follows. Firstly, the paper clarifies the concept of e-government and reviews success factors of e-government proposed by various authors in literature. Secondly, the success factors for adopting e-government in Poland are identified and the model of success factors is proposed. This model embraces the four categories of success factors. They are: economic, socio-cultural, technological and organizational. All the factors are considered in three stages: (1) ICTs access (supply) - reflecting technical and economic accessibilities of ICTs, (2) ICTs competences - reflecting competences and awareness related to the use of ICTs, (3) ICTs use (demand) - reflecting actual usage of ICTs in the government units. The paper concludes by discussing its findings, limitations, implications, and avenues for further research.

This work contributes to extant research by showing a holistic approach to the success factors for adopting e-government, especially in transition economies. Researchers and scholars who develop studies on e-government could find significant guidelines in this paper. Moreover, for practitioners, the results of this study can be used to undertake empirical activities aimed at e-government adoption, ultimately helping them reap more benefits from their activities.

\section{THEORETICAL UNDERPINNINGS}

\section{A Brief Introduction to E-Government}

The concept of e-government was coined by several researchers and scholars $[6,13,23,34,35,50,55,63,68,69$, $75,78,82,83,84]$. Furthermore, since 2003 the Gartner Group [9] and the Deloitte [26] have laid the foundations for e-government and have been creating solutions for its development. Moreover, such organizations as: the European Commission [18, 19, 20, 21, 22] OECD [73] and the World Bank [1] are involved in the discourse on e-government.

Generally, e-government has been defined as the application of ICTs to transform the efficiency, effectiveness, transparency and accountability of informational and transactional exchanges within government units, between government units at state and local levels, citizens and businesses; and to empower citizens through access and use of public information and public services. Those researches and works allow to draw the following connotation of egovernment. The e-government denotes:

- improving government processes by using ICTs and government process management (e-administration);

- providing government services electronically for citizens, businesses, employees and other stakeholders (e-government services);

- improving transparency and democratic decision making, as well as citizen's participation (e-democracy);

- developing cooperation, networking and partnerships between government units, citizens and business (egovernance).

The holistic understanding of e-government requires careful deliberation on its different issues and for its successful adoption. E-government involves a multidimensional approach embracing the consideration (from the strategic layer to the technical layer) of distinct aspects (organizational, economic, cultural, social, political, and organizational) and the core phases of e-government (from information to personalization level of e-government maturity). Among other things, enumeration of success factors that are crucial for adopting e-government is becoming an important task.

\section{Critical Success Factors for E-Government Adoption}




\section{Issues in Information Systems \\ Volume 14, Issue 2, pp.87-100, 2013}

An important challenge is to identify factors that determine the success of e-government adoption. Success factors are these areas and operations which should be focused on primarily in order to achieve the most satisfying results of e-government adoption [83, 84]. The theory of critical success factors (CSFs) [46, 67, 5] gives sound basis for stating what criteria should be followed during e-government adoption.

In the literature there are several definitions of critical success factors for e-government. The UN argued on macro factors as determinants of e-government [45]. It described social, political and economic conditions and a correlation between country's conditions with its level of e-government maturity. In Oyomno' approach, ICT infrastructure development, human resources capability, leadership and management at the organizational level determine the egovernment successful adoption [60]. Similarly, Norris, Moon and Reddick defined organizational factors such as website age, size of an organization, manager's professionalism and they have studied the influence of those factors on e-government $[65,56]$.

Among other factors determining the e-government development are cited: ICT infrastructure development, law and public policy, digital divide, e-literacy, accessibility, trust, privacy, security, transparency, interoperability, records management, permanent availability and preservation, education and marketing, public/private competition/collaboration, workforce issues, cost structures and benchmarking [3]. Marche and McNiven, analyzing factors for e-government adoption, took into account: citizen privacy and security, adequately skilled citizens and government employees, and the elimination of tendency for e-government to replicate traditional government [25, 54]. Those factors were confirmed by Ebrahim and Irani [28]. Moreover, the authors identified such CSFs as ICT infrastructure, organizational, operational cost.

The efforts of the UK government in realizing its e-government target helped to illustrate two perspectives of egovernment constraints: a citizens' perspective and a government's perspective [17]. The most important constraints of the citizens' perspective were: lack of internet access, disparities in computer knowledge, generation gap, lack of awareness, language barrier, security fears, lack of trust, un-user-friendly web sites. Regarded as the most important constraints from the government's perspective were: lack of finances, lack of skills and technology, political pressures, data protection and security laws, staff resistance to change.

Other authors classified possible threat sources to e-government into five groups: (1) organizational (i.e. undefined strategy, procedures and regulations, poor leadership, poor security policy), (2) technological (i.e. hardware, software, interface, e-services, e-mail, e-administration), (3) human (i.e. low ICT skill /capability, unawareness, terminated employees, negligent, dishonest, lack of knowledge, culture resistance /seniority, dissatisfaction), (4) natural (i.e. fire, sand/dust storm, lightning), and (5) environmental (i.e. power failure) [71].

ICTs accessibility and quality are positively influencing e-government [64]. Additionally, research is conducted on CSFs influence on - effective IT governance in the government units from developing countries. It is proposed to divide CSTs into four groups. Those are: (1) strategic alignment, (2) value delivery and risk management, (3) resource management, and (4) performance measurement [58].

Culture, as a source of acceptable norms and behaviors, may influence online expectations, preferences, and experiences of individuals and their attitudes towards e-government [79]. A study on the relationship between national culture and e-government were conducted by Kovacic [48]. Kovacic's study was done from a supply (government's) perspective rather than from a demand (citizens) perspective and used the largest worldwide data sets to test the correlation between culture and e-government readiness. Kovacic found that national culture has a moderate impact on the e-government readiness, although individualism and power distance were the only significant variables. Research in this field was also carried out by Zhao [79]. Unlike Kovacic, he studied the influence of national culture on e-government adoption from both a supply and a demand perspective. Zhao's findings showed that overall, national culture influences e-government development. The countries with a national culture that favors individualism, and/or small power distance, and/or long term orientation perform better in egovernment development.

A significant group of CSFs for e-government adoption are social factors. The negative impact of e-government is related to the social exclusion, especially "digital divide" that reflects a state where some groups do not have access to computers and the internet [52]. For example among the causes of digital divide, which simultaneously influence 


\section{Issues in Information Systems \\ Volume 14, Issue 2, pp.87-100, 2013}

e-government adoption Asgarkhani identified: lack of telecommunications and network infrastructure; limited PC access; lack of financial resources for developing ICT infrastructure; lack of ICT literacy; limited internet access; cultural resistance; high access costs to global networks and the Internet; high cost of business investment; strategic business impediments - applicability; divides between countries; social divides within countries; divides within countries related to income, education, age, family type, location; business divides related to sector, region, firm size [7]. Except for digital divide, the success of e-government can be influenced by social implications which include: information security, impact on jobs and workplaces, impact on individuals' rights and privacy, potential impact on society, impact on social interaction [7].

The studies on CSFs for successful e-government adoption were also conducted in Central and Eastern Europe. The research showed that higher levels of human capital resources, greater human capabilities and knowledge, rule of law, the availability of ICT infrastructure and more ICT amenities have positive effects on e-government. Whereas, transparency levels (i.e. low corruption perceptions), national wealth and government efficiency are not positively related to e-government adoption [41].

There are several models of CSFs for e-government adoption, some of which are presented above. However, there is a lack of research on this issue in developing European countries. Hence, there is a need to suggest a model that incorporates critical factors contributing to the success in e-government adoption in the transition economies of Central and Eastern Europe.

\section{RESEARCH METHODOLOGY}

This study is a part of research on the holistic and systems approach to the sustainable information society [81]. One of the areas identified for future research relates to critical success factors for sustainable information society development. At the same time, the key nexus in the sustainable information society is a well-functioning public administration and an e-government in particular [86]. Among others, the following research question was posed:

RQ: Which areas and operations of government units should be primarily focused on in order to achieve the most satisfying results of transition from a government to an e-government? [81].

Consequently, this study sought to examine critical factors for successful e-government adoption. This was a complex issue and it required research tasks of cognitive, conceptual and methodological characteristics. Such a spectrum of work involved adaptation of research methods to specific individual tasks and required the use of various research tools. These were: a critical review of literature, action research [29, 51], brainstorming [76], the Delphi technique $[53,24,40]$ and logical deduction.

The general purposes of a literature review were to critically appraise and synthesize the current state of knowledge relating to the CSFs for e-government adoption and identify gaps in this knowledge that a new study would seek to address. The aim of action research was to find CSFs for e-government adoption in Poland that is to find "a solution to a local problem in a local setting" [29,51]. Action research means the collaboration of this paper authors with the Silesian Centre of Information Society (SCSI). The SCSI is responsible for information society development, as well as e-government, in the Silesian Voivodeship, Poland. Brainstorming was used in the middle stage of CSFs model development, when new ideas and solutions of the CSFs model were required. Whereas, the Delphi technique was employed for gathering knowledge on CSFs from respondents within their domain of expertise and for verifying and developing the model of success factors. For the purpose of delving deeply into the practical value of this model, this study adopted action research and the Delphi technique.

In order to propose a model of success factors for e-government adoption this research took the following stages. Firstly, a review of literature was conducted to identify CSFs for e-government adoption presented in the literature. Secondly, basing on literature findings, empirical observations concerning e-government adoption in the Silesian Voivodeship and brainstorming of the paper authors, this study established a prototype model of success factors for e-government. Thirdly, thanks to the Delphi technique this model was verified and developed. The Delphi process was iterated until consensus on success factors for e-government adoption has been achieved. 


\section{Issues in Information Systems \\ Volume 14, Issue 2, pp.87-100, 2013}

21 experts participated in the Delphi study. The selection of experts was made in such a manner as to combine knowledge and experience of scholars, researchers and practitioners. The experts were (Table 1):

- employees of local and state government (16), who are responsible for ICTs and e-government adoption; and

- professors of Polish universities (6), who conduct studies and empirical research on information society and e-government.

The Delhi study employed multiple iterations designed to develop a consensus of opinion concerning CSFs for e-government adoption. The process was viewed as a series of rounds. In the early rounds four experts participated, in the last round all experts listed in Table 1 participated in the Delphi research. In each round every expert dealt with and felt out a questionnaire which was delivered to a researcher who gathered, organized, and gave back to every expert an account of the standpoint of the whole group and the expert's own opinion. A summary of opinions expressed by each expert made them aware of the range of positions and the reasons underlying those positions. In the last round the experts evaluated the strength of influence of particular factors on e-government adoption. A Likert scale was used in the evaluation. The experts had to answer the question: In a scale $1-5$ state to what extend do you agree that the following factors influence the development of e-government? The scale respectively represented: 1 - disagree strongly, 2 - disagree, 3 - neither agree nor disagree, 4 -agree, 5 -agree strongly.

Table 1. Delphi study experts

\begin{tabular}{|c|c|c|c|}
\hline No. & Title & Government sector & Government unit \\
\hline 1. & Minister Counselor & State government & The Ministry of Administration and Digitization \\
\hline 2. & Deputy Director for European Affairs & State government & Centre for Health Information Systems \\
\hline 3. & Director & State government & Central Statistical Office, Szczecin \\
\hline 4. & IT Team Manager & Local government & Marshal's Office Silesian Voivodeship \\
\hline 5. & SEKAP Project Coordinator & Local government & Marshal's Office Silesian Voivodeship \\
\hline 6. & Deputy Director & Local government & Silesian Center for the Information Society \\
\hline 7. & $\begin{array}{l}\text { Design and Development of } \\
\text { E-government Services Specialist }\end{array}$ & Local government & Silesian Center for the Information Society \\
\hline 8. & Head of IT Department & Local government & Dąbrowa Górnicza City Hall \\
\hline 9. & Head of IT Department & Local government & Jaworzno City Hall \\
\hline 10. & Junior Inspector of IT Department & Local government & Jaworzno City Hall \\
\hline 11. & $\begin{array}{l}\text { Chief Specialist - coordinator of office } \\
\text { IT services }\end{array}$ & Local government & Kalisz City Hall \\
\hline 12. & Head of IT Department & Local government & Katowice City Hall \\
\hline 13. & $\begin{array}{l}\text { Representative of the President for the } \\
\text { Promotion of Innovativeness }\end{array}$ & Local government & Katowice City Hall \\
\hline 14. & IT Team Manager & Local government & Mysłowice City Hall \\
\hline 15. & Head of IT Department & Local government & Zawiercie District Office \\
\hline 16. & $\begin{array}{l}\text { Inspector of Information Technology } \\
\text { and Telecommunications }\end{array}$ & Local government & Żywiec City Hall \\
\hline 17. & Professor & Univeristy & Warsaw School of Economics \\
\hline 18. & Professor & Univeristy & Warsaw School of Economics \\
\hline 19. & Professor & Univeristy & Poznan University of Economics \\
\hline 20. & Professor & Univeristy & University of Economics in Katowice \\
\hline 21. & Professor & Univeristy & University of Economics in Katowice \\
\hline 22. & Professor & Univeristy & University of Economics in Katowice \\
\hline
\end{tabular}

\section{RESEARCH FINDINGS}

\section{Perspectives of Success Factors for E-Government Adoption}

The conducted research has allowed to indicate several factors of success for e-government adoption. These factors play different roles in the e-government adoption, from great to small importance. They are of different characteristics related to ICTs supply and demand as well as e-government stakeholders and their ICTs competences. ICTs mean hardware (computers, networks, mobile phones) and software (back-office and front-office information systems, e-government service, websites). In this briefing note, Government-to-Citizens (G2C) and 


\section{Issues in Information Systems \\ Volume 14, Issue 2, pp.87-100, 2013}

Government-to-Business (G2B) services are categorized as front-office, and Government-to-Government (G2G) as back-office. ICTs themselves would not guarantee success with e-government. It is necessary that any e-government initiative must ensure that it has sufficient resources, adequate ICT infrastructure, management support, capable ICT staff, and effective ICT training and support, coordination and management of e-government, as well as egovernment stakeholders' competences related to use of the ICTs potential.

Empirical data suggest that the adoption of e-government is conditioned by many factors of economic, socialcultural, technological and organizational characteristics. Firstly, there is a positive relationship between economic factors and e-government adoption. The economic factors are related to the national wealth, the economic wellbeing of nation, the financial situation of government stakeholders, the availability of economic endowments, risks of failure of adopting e-government as well as the economic benefits. Secondly, socio-cultural factors positively influence the adoption of e-government. The Delphi study experts have also shown the existence of a positive relationship between the mentality and awareness of e-government stakeholders, digital divide, information culture, digital culture and the e-government adoption. Thirdly, technological characteristics positively influence the adoption of e-government. These factors are related to ICTs innovations, innovative e-government services, open source software licenses, integration of front-office and back-office information systems, user-friendly information systems, maturity of e-government, ICT standardization, competitive ICT professionals, and quality of egovernment services. Fourthly, the experts have indicated that the e-government adoption depends on organizational factors, such as rule of law, managerial innovation, and management of ICTs.

Furthermore, empirical data suggests that e-government adoption requires:

- technical and economic accessibilities of ICTs - ICTs access (supply) stage;

- competences and awareness related to the use of ICTs - ICTs competences and awareness stage; and

- usage of ICTs by government units, citizens and businesses - ICTs use (demand) stage.

Consistent with the tenets espoused in our early research on information society and these research findings, the success factors model for e-government adoption is presented in Figure 1. It is designed to highlight the relationships between relevant factors and the dependent variable - e-government adoption.

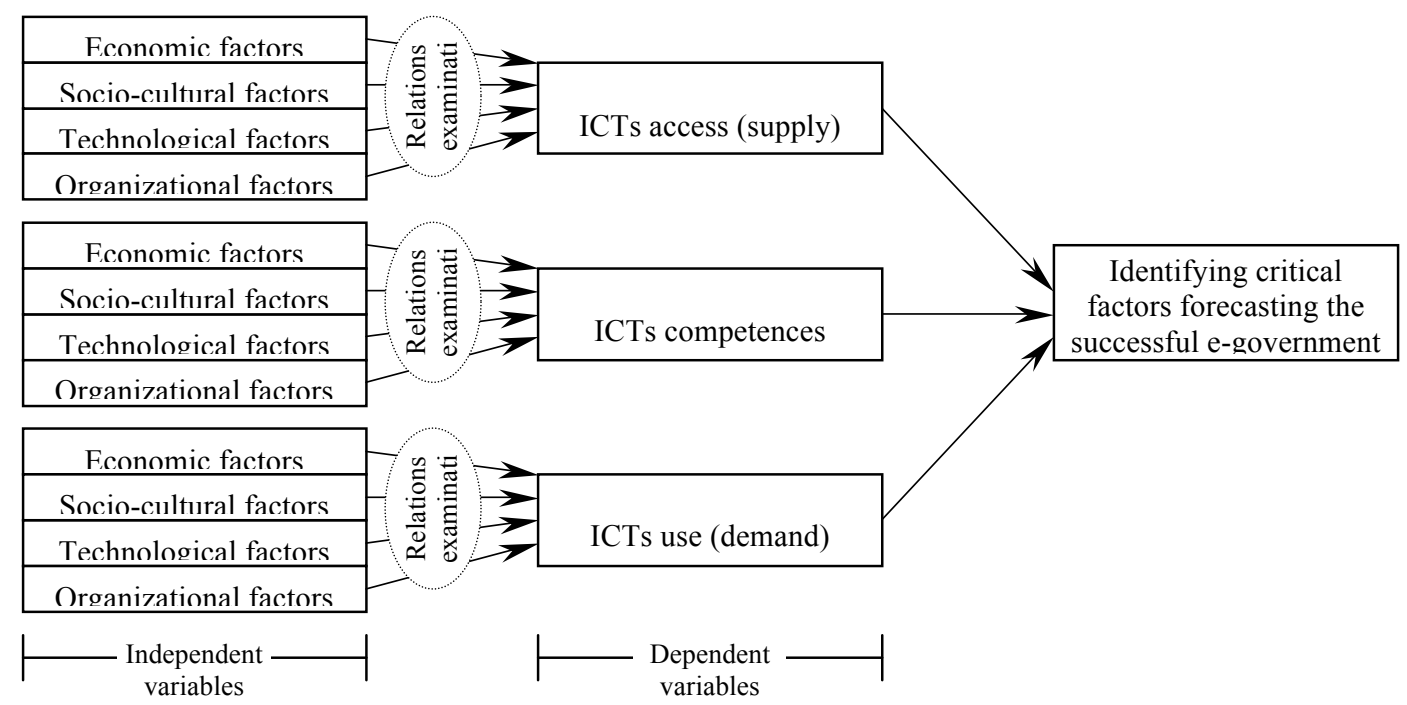

Figure 1. Proposed conceptual model of success factors for e-government adoption

\section{Economic Factors Related to E-Government Adoption}

Some economic factors are related to successful adoption of e-government as shown in Table 2. The public and private financial outlays on ICTs are of paramount importance among them. This includes both investments in 


\section{Issues in Information Systems \\ Volume 14, Issue 2, pp.87-100, 2013}

computers, networking and telephony, as well as back-office information systems, front-office information and egovernment services, in particular. No less important for e-government adoption are the financial situation of government units and the associated possibility of financing the purchase, implementation and maintenance of ICTs. Very important are also public and private funding of education in ICT for government managers and other employees. Outlays on the creation of centers of ICTs competence in public administration were also mentioned as an important economic success factor, which may take the form of databases of knowledge, ideas and concepts, forums, portals and online counseling. In the countries of Central and East Europe investments related to the implementation of e-government are often financed with European Union founds. The sources of public grants and subsidies are: Regional Operational Programmes and Operational Programme "Innovative Economy" financed from the European Regional Development Fund as well as the Operational Programme "Human Capital" financed from the European Social Fund. Private outlays are firms' outlays, for example, to build a network or personal expenses, such as education. According to experts, the least important economic factor influencing e-government adoption is the economic risk.

Table 2. Economic success factors for adopting e-government

\begin{tabular}{|c|c|c|c|c|c|c|c|}
\hline \multirow{13}{*}{ 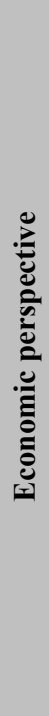 } & \multirow{2}{*}{ Stages } & \multirow{2}{*}{ Critical success factors } & \multicolumn{5}{|c|}{ Influence } \\
\hline & & & 5 & 4 & 3 & 2 & 1 \\
\hline & \multirow{4}{*}{$\begin{array}{l}\text { ICTs access } \\
\text { (supply) }\end{array}$} & $\begin{array}{l}\text { Public subsidies and private outlays on hardware, networks and } \\
\text { telecommunications }\end{array}$ & 17 & 5 & & & \\
\hline & & Competition on ICT market & 6 & 12 & 2 & 2 & \\
\hline & & $\begin{array}{l}\text { Public outlays on back-office and front-office information } \\
\text { systems, especially e-government services }\end{array}$ & 16 & 3 & 2 & 1 & \\
\hline & & Financial situation of government units & 14 & 4 & 2 & 2 & \\
\hline & \multirow{3}{*}{ ICTs competences } & $\begin{array}{l}\text { Public and private outlays on ICTs education for government } \\
\text { managers }\end{array}$ & 9 & 13 & & & \\
\hline & & $\begin{array}{l}\text { Public and private outlays on ICTs education for government } \\
\text { employees }\end{array}$ & 6 & 15 & 1 & & \\
\hline & & Outlays on creating ICT competence centers government units & 9 & 7 & 3 & 3 & \\
\hline & \multirow{4}{*}{$\begin{array}{l}\text { ICTs use } \\
\text { (demand) }\end{array}$} & Financial situation of government units & 14 & 4 & 2 & 2 & \\
\hline & & $\begin{array}{l}\text { Potential economic benefic coming from ICTs usage in } \\
\text { government units }\end{array}$ & 8 & 8 & 2 & 4 & \\
\hline & & Economic risk of ICTs implementation in government units & 1 & 5 & 7 & 6 & 1 \\
\hline & & Public outlays on ICTs promotion in government units & 6 & 7 & 5 & 3 & \\
\hline
\end{tabular}

\section{Socio-Cultural Factors Related to E-Government Adoption}

The socio-cultural transition leads to successful implementation of e-government. The detailed results of the identified socio-cultural factors are presented in Table 3. ICTs awareness of government officials (managerial workers) is an important factor. Managers can minimize or recognize the role of ICTs in public administration, which, to a very large extend, influences decision-making on investment and the use of ICTs. Another, according to experts, very important and an important success factor is the absorption of e-government services through egovernment stakeholders. For example, the reported demand for e-government services by government stakeholders and extensive use of already provided e-government services both bear a very positive effect on e-government. Experts point to a culture of information conducive to the use of ICTs as a success factor for e-government adoption. It is mainly about a new culture of work with information and ICTs, operating in multicultural environments, building trust, building relationships and networks, sharing knowledge. Information culture can be expressed through the use of electronic document management system and electronic signature, the involvement of government employees in the process of defining requirements for information systems and the testing process. A manifestation of this culture is the shared responsibility for the implementation of information systems, the integration of government stakeholders, building trust in e-government services, encouraging (by government employees) citizens and businesses to electronic forms of contact with the government units, cooperation between government units. New social and cultural competences of government employees are very important to create such an information culture. The smallest impact on the development of e-government bears social exclusion. 


\section{Issues in Information Systems \\ Volume 14, Issue 2, pp.87-100, 2013}

Table 3. Socio-cultural success factors for adopting e-government

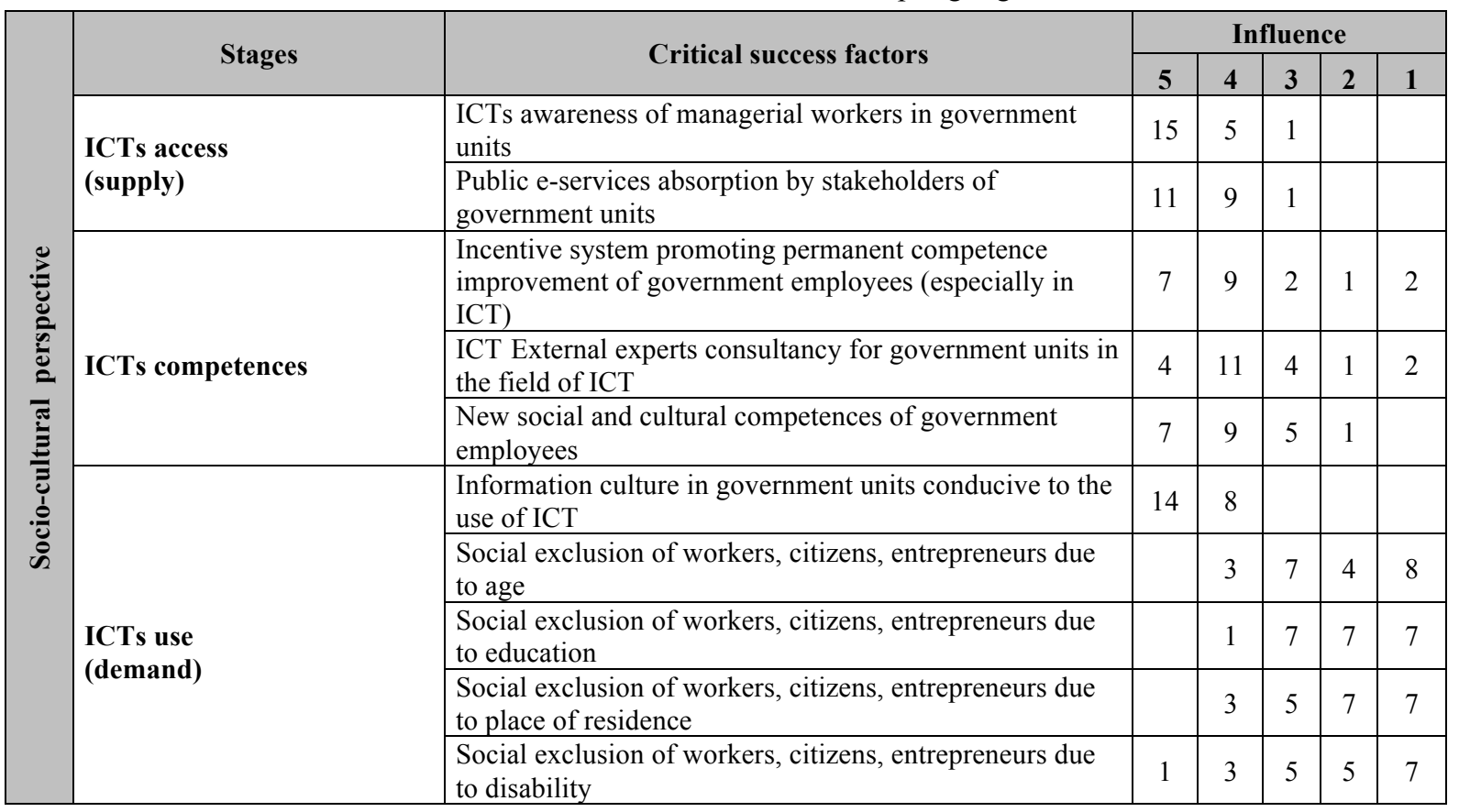

\section{Technological Factors Related to E-Government Adoption}

This research confirmed that there is a significant association between technological factors and e-government adoption. Quality of front-office and back-office systems is one of the most significant factors, especially quality of e-government services. Attention has been paid to the following quality standards: functionality, reliability, usability, efficiency, maintainability and portability $[43,44]$. In the opinion of experts e-government adoption is strongly influenced by the maturity of e-government services $[74,27,84]$. E-government services at the $4^{\text {th }}$ level of maturity, called transaction (full electronic) and at the $5^{\text {th }}$ level called personalization (targetisation/automation) [83] determine e-government adoption. It needs to be stressed that the highest levels of maturity require architecture interoperability [83]. Important success factors are innovative ICTs, e.g. broadband and next generation access networks (NGA/NGN), mobile devices, innovative e-government services, government process management systems. ICTs leaderships and ICTs visionaries, and high ICTs competence of government employees have profound influence on e-government implementation. The all identified technological success factors are positively related to e-government adoption are presented in Table 4.

Table 4. Technological success factors for adopting e-government

\begin{tabular}{|c|c|c|c|c|c|c|c|}
\hline \multirow{12}{*}{ 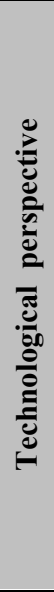 } & \multirow{2}{*}{ Stages } & \multirow{2}{*}{ Critical success factors } & \multicolumn{5}{|c|}{ Influence } \\
\hline & & & 5 & 4 & 3 & 2 & 1 \\
\hline & \multirow{6}{*}{$\begin{array}{l}\text { ICTs access } \\
\text { (supply) }\end{array}$} & Innovative hardware and networks in government units & 12 & 6 & 2 & 2 & \\
\hline & & Innovative e-government services & 18 & 1 & 2 & 1 & \\
\hline & & Open source software licenses & 6 & 7 & 9 & & \\
\hline & & Standardized ICTs for government units & 9 & 10 & 1 & 1 & \\
\hline & & Dedicated (personalized) ICTs for government units & 10 & 8 & 2 & 1 & \\
\hline & & Coopetition on ICT market & 3 & 3 & 10 & 4 & \\
\hline & \multirow{2}{*}{ ICTs competences } & ICT leaderships and visionaries in government units & 13 & 7 & 2 & & \\
\hline & & ICT competences of government employees & 14 & 7 & & 1 & \\
\hline & \multirow{2}{*}{$\begin{array}{l}\text { ICTs use } \\
\text { (demand) }\end{array}$} & $\begin{array}{l}\text { Integration of front-office and back-office information } \\
\text { systems }\end{array}$ & 15 & 6 & 1 & & \\
\hline & & Quality of e-government services & 20 & 1 & & 1 & \\
\hline
\end{tabular}




\section{Issues in Information Systems \\ Volume 14, Issue 2, pp.87-100, 2013}

Maturity of e-government services

$15|4|$

\section{Organizational Factors Related to E-Government Adoption}

The most important factors for e-government adoption are related to organizational factors. The resulting set of these factors is given in Table 5. It is reasonable to expect that where e-government leaderships (visionaries) to drive egovernment initiatives exist, there will be little or no problems in adopting e-government. Moreover, coordination of public ICT investments and top management support were identified as major factors. Several experts highlighted that electronic communication between government units (G2G model) [11] and adaptation of new management models in government units positively influences the adoption of e-government. These new models are: knowledge management, government processes management, electronic document management, workflow management. Egovernment adoption is determined by the rule of law. Here are listed legal regulations mainly concerning intellectual property, digital signatures, data protection, public procurement, interoperability, electoral law.

Table 5. Organizational success factors for adopting e-government

\begin{tabular}{|c|c|c|c|c|c|c|c|}
\hline & Stages & Critical success foctors & & Inf & lenc & & \\
\hline & Stages & Critican success tactors & 5 & 4 & 3 & 2 & 1 \\
\hline & & Coordination of public ICT investments & 12 & 6 & & 3 & \\
\hline & & Public-Private Partnership in the field of ICTs & 1 & 9 & 10 & 1 & 1 \\
\hline & & Rule of law & 9 & 7 & 3 & 2 & \\
\hline & $\begin{array}{l}\text { ICTs access } \\
\text { (supply) }\end{array}$ & $\begin{array}{l}\text { Institutional support for the development of ICT } \\
\text { infrastructure }\end{array}$ & 8 & 7 & 5 & 2 & \\
\hline$\sum_{0}^{0}$ & & $\begin{array}{l}\text { Access for employees of government units to their } \\
\text { network resources }\end{array}$ & 5 & 4 & 5 & 5 & 1 \\
\hline के & & ICT benchmarking for local and state government & 2 & 10 & 6 & 2 & 1 \\
\hline $\bar{\Xi}$ & & Approved e-government strategy & 7 & 10 & 3 & 2 & \\
\hline క & & E-government leaderships and visionaries & 13 & 7 & 2 & & \\
\hline : & ICTs competences & $\begin{array}{l}\text { The competence of employees of government units in the } \\
\text { field of new management models }\end{array}$ & 7 & 9 & 5 & 1 & \\
\hline 咅 & & ICT benchmarking for local and state government & 2 & 10 & 6 & 2 & 1 \\
\hline on & & Approved e-government strategy & 7 & 10 & 3 & 2 & \\
\hline & & Top management support & 12 & 6 & & 3 & \\
\hline & & $\begin{array}{l}\text { Adaptation of new management models in government } \\
\text { units }\end{array}$ & 9 & 11 & 1 & & \\
\hline & $\begin{array}{l}\text { ICTs use } \\
\text { (demand) }\end{array}$ & $\begin{array}{l}\text { Participation of employees of government units in } \\
\text { organizational changes }\end{array}$ & 4 & 10 & 3 & 2 & 2 \\
\hline & & Electronic communication between government units & 14 & 8 & & & \\
\hline & & $\begin{array}{l}\text { New ways of providing work by employees of } \\
\text { government units }\end{array}$ & 3 & 8 & 9 & 1 & \\
\hline
\end{tabular}

\section{DISCUSSION}

The research findings have several implications for e-government practitioners, or those involved in e-government projects.

Adoption of e-government requires: (1) technical and economic accessibilities of ICTs - ICTs access (supply), (2) competences and awareness related to the use of ICTs - ICTs competences, and (3) usage of ICTs by government units, citizens and businesses - ICTs usage (demand). Our studies and experiences confirmed there is some gap between the supply of ICTs in government units (e-government) and actual usage of ICTs (e-government). ICTs access means ICT infrastructure investments in government units. This concerns in particular the purchase of hardware, construction of infrastructure networks and the implementation of the standard or creation of the dedicated back-office and front-office information systems. ICTs investments in themselves do not mean success in adopting e-government. They must involve a variety of organizational, social and cultural changes that lead to 


\section{Issues in Information Systems \\ Volume 14, Issue 2, pp.87-100, 2013}

improvement of efficiency, transparency, and accountability in government units by reducing transaction times and removing redundant layers of bureaucracy. Lack of relevant changes, such as re-engineering of government processes and documents workflows or adaptation of the law, usually means that the implementation of ICTs does not bring the expected benefits. Low quality and lack of integration of information systems and their lack of adaptation to the needs of users can be even a cause of failure to use ICTs. In particular, this relates to the egovernment services for citizens and businesses. Thus, in addition to ICTs supply, the adopting e-government is also determined by ICTs demand. Competences of government managers and employees are very important for these two stages. Their knowledge and skills are needed to take appropriate investment decisions, implement ICTs and successfully use ICTs.

In sum, there are four groups of factors that government leaders should consider in successful adopting egovernment at the three above stages. Firstly, a long-term economic plan with a clearly articulated financial strategy of ICTs supply, competences and usage funded by the government, the European Union and businesses (publicprivate partnership) is vital to the adoption of e-government. Successful e-government adoption requires financing of not only ICTs investments, but also ICTs usage and ICTs competence improvement. Secondly, socio-cultural factors influence the adoption of e-government. This research provides evidence in support of the positive, direct associations between e-government adoption and information culture, awareness government stakeholders of a given e-government or of its benefits as well as new stakeholders competences focused on information. Thirdly, adoption of e-government is determined by technological factors. Innovative ICTs, e-government services at the highest level of maturity, very good-quality e-government services and integration of front- and back-office information systems enhance the exponential adoption of e-government. Moreover, ICT leaderships and visionaries in government units and their high ICT competences spur on-going efforts to adopt e-government. Fourthly, organizational requirements are necessary for the adoption of e-government. Coordination of public ICT investments and top management support, implementation of new management models and rule of law create favorable conditions for e-government adoption.

The identifying and understanding success factors of e-government bear significance for reliable and effective e-government adoption. The most important challenge to overcome in this respect is to realize that there is no one solution to fit every situation. European countries are characterized by vastly different political, economic, social and governance contexts, which require different approaches. Proposed model is easy to adjust quickly to the new conditions.

\section{CONCLUSIONS}

Generally speaking, the adoption of e-government poses a challenge, and thus is an interesting subject of research. This research puts an effort to make some contribution to the development of studies on e-government, especially on CSFs for successful e-government adoption. It explores e-government concept, investigates CSFs for e-government by reviewing the literature, identifies a comprehensive set of CSFs by action research, brainstorming and the Delhi study. Finally, it proposes the model of CSFs. We employed experts from 15 local and state governments and 6 Polish universities to provide insight. The research findings showed that economic, socio-cultural, technological and organizational factors (e.g. national wealth, human capital, ICT infrastructure, rule of law, organizational changes, leaderships support) matter in accelerating country's ability and willingness to implement e-government successfully.

Those identified CSFs are not unique to the e-government in Poland. They are universally applicable to a general egovernment in any country. The proposed model can be definitely useful for transition economies, especially in Central and East Europe. Government practitioners could find answers to an important question: which areas and operations of government units should be primarily focused on in order to achieve the most satisfying results of transforming from government to e-government. This research suggests important issues for programming, building and developing the e-government. The replication of this study in emerging and developing countries will be useful to improve their knowledge related to the factors impacting e-government adoption (or lack thereof) in such contexts.

The model of success factors for e-government adoption showed in this research should be explored in greater depth. By focusing on longitudinal research and expanding the number of local government units that will be 


\section{Issues in Information Systems \\ Volume 14, Issue 2, pp.87-100, 2013}

studied, the authors hope to evaluate this model and identify the barriers and facilitators of e-government adoption in Poland. Moreover, ranks of the identified CSFs will be examined. All these factors will be prioritized in different contexts, for instance, economic, socio-cultural, organizational, technological, ICT access, ICT competences, and ICT use. This research is and will continue to be conducted in the next months. Furthermore, there is also a need to conduct more in-depth research on e-government, especially into: (1) improving government processes by using government process management and ERP systems, (2) providing e-government services at the highest level of maturity, (3) exploring "best practices" to be used to successfully adopt e-government, and (4) investigating "demand-side" of e-government from the viewpoint of citizens and businesses view. Those will be considered as future work.

\section{ACKNOWLEDGEMENTS}

This research has been supported by a grant entitled "Designing a system approach to sustainable development of the information society - on the example of Poland" from the National Science Centre in Poland, 2011/01/B/HS4/00974, 2011-2014.

\section{REFERENCES}

1. A Definition of E-Government. (2003). Washington DC: The World Bank.

2. AlAwadhi, S., \& Morris, A. (2009). Factors influencing the adoption of e-government services. Journal of Software, 4(6), 584-590.

3. Almarabeh, T., \& AbuAli, A. (2010). A general framework for e-government: Definition maturity challenges, opportunities, and success. European Journal of Scientific Research, 39(1), 29-42.

4. Andersen, K.N., Medaglia, R., Vatrapu, R., Henriksen, H.Z., \& Gauld R. (2011). The forgotten promise of egovernment maturity: Assessing responsiveness in the digital public sector. Government Information Quarterly, 28, 439-445.

5. Angelopoulos, S., Kitsios, F., \& Papadopoulos, T. (2010). New service development in e-government: identifying critical success factors. Transforming Government: People, Process and Policy, 4(1), 95-118.

6. Anttiroiko, A. V. (2008). A brief introduction to the field of e-government. In A. V. Anttiroiko (Ed.), Electronic Government: Concepts, Methodologies, Tools, and Applications, (pp. xli-lxxv). New York: Hershey.

7. Asgarkhani, M. (2005). Digital government and its effectiveness in public management reform: A local government perspective, Public Management Review, 7(3), 465-487.

8. Avgerou, C. (2010). Discourses on ICT and development. Information Technologies and International Development, 6(3), 1-18.

9. Baum, C. H., \& Maio, A. D. (2000). Gartner's Four Phases of E-government Model, London: Gartner Group. Available: http://www.gartner.com/id=317292.

10. Berleur, J., Hercheui, M. D., \& Hilty, L. M. (2010). (Eds.), What kind of information society? Governance, virtuality, surveillance, sustainability, resilience, Proceedings of 9th IFIP TC 9 International Conference, HCC9, and 1st IFIP TC 11 International Conference, CIP 2010 Held as Part of WCC 2010, Brisbane: IFIP.

11. Beynon-Davies, P. (2007). Models for e-government. Transforming Government: People, Process and Policy, 1(1), 7-28.

12. Blackman, C. (2004). Stumbling along or grave new world? Towards Europe's information society. Foresight, 6(5), 261-270.

13. Brainard, L. A., \& McNutt, J. G. (2010). Virtual government-citizen relations: Informational, transactional or collaborative? Administration \& Society, 42(7), 836-858.

14. Cheng, J. H. (2011). Inter-organizational relationships and information sharing in supply chains. International Journal of Information Management, 31(4), 374-384.

15. Chetty, S., \& Agndal, H. (2007). Role of inter-organizational networks and interpersonal networks in an industrial district. Regional Studies, 00.00, 1-13.

16. Choe, J.M. (2011). How to classify the types of inter-organizational relationships in manufacturing firms. African Journal of Business Management, 5(15), 6500-6514.

17. Choudrie, J., Weerakkody, V., \& Jones, S. (2005). Realising e-government in the UK: rural and urban challenges. Journal of Enterprise Information Management, 18(5), 568-585. 


\section{Issues in Information Systems \\ Volume 14, Issue 2, pp.87-100, 2013}

18. COM (1999). 687 final, eEurope - An Information Society For All. Communication of 8 December 1999 on a Commission initiative for the special European Council of Lisbon, 23 and 24 March 2000, Available: http://europa.eu/legislation_summaries/information_society/strategies/index_en.htm, 2012.

19. COM (2001). 140 final, eEurope 2002: Impact and Priorities. Commission Communication of 13 March 2001 on a Communication to the Spring European Council in Stockholm, 23-24 March, Available: http://europa.eu/legislation_summaries/information_society/strategies/index_en.htm, 2012.

20. COM (2003). 567, The Role of eGovernment for Europe's Future. Communication of 26 September 2003 from the Commission to the Council, the European Parliament, the European Economic and Social Committee and the Committee of the Avegions, Avalable: http://europa.eu/legislation_summaries/information_society/strategies/index_en.htm, 2012.

21. COM (2006). 173 final, i2010 eGovernment Action Plan-Accelerating eGovernment in Europe for the Benefit of All. Available: http://europa.eu/legislation_summaries/information_society/strategies/index_en.htm, 2012.

22. COM (2010). 2020 final, EUROPE 2020 A Strategy for Smart, Sustainable and Inclusive Growth. European Commission, Available: http://europa.eu/legislation_summaries/information_society/strategies/index_en.htm, 2012.

23. Cordella, A., \& Lannacci, F. (2010). Information systems in the public sector: The e-government enactment framework. Journal of Strategic Information Systems, 19, 52-66.

24. Dalkey, N.C., Rourke, D. L., Lewis, R., \& Snyder D. (1972). (Eds.), Studies in the quality of life: Delphi and decision-making. MA: Lexington Books.

25. Davison, R.M., Wagner, C., \& Ma, L.C.K. (2005). From government to e-government: a transition model. Information Technology \& People, 18(3), 280-299.

26. Deloitte (2000). At the Dawn of e-Government. The Citizen as Customer. New York: Deloitte Research.

27. Digitizing Public Services in Europe: Putting ambition into action, (2010) 9th Benchmark Measurement, 244245, Capgemini, IDC, Rand Europe, European Commission.

28. Ebrahim, Z., \& Irani, Z. (2005). E-government adoption: architecture and barriers. Business Process Management Journal, 11(5), 589-611.

29. Ellis, T.J, \& Levy, Y. (2009). Towards a guide for novice researchers on research methodology: Review and proposed methods. Issues in Informing Science and Information Technology, 6, 323-337.

30. Evans, N., \& Price, J. (2012). Barriers to the effective deployment of information assets: An executive management perspective. Interdisciplinary Journal of Information, Knowledge, and Management, 7, 178-199.

31. Ferris, S. P. (2012). Teaching, learning and the net generation: Concepts and tools for reaching digital learners, Hershey: IGI Global.

32. Fuchs, Ch. (2006). Sustainability and the information society. In Berleur, T., Numinen, M.I., \& Impagliazzo, T. (Eds.), Social Informatics: An Information Society for All? In Remembrance of Rob Kling, International Federation for Information Processing. Vol. 223, 219-230. Boston: Springer.

33. Garcia-Sanchez, I.M., Cuadrado-Ballesteros, B., \& Frías-Aceituno, J.V. (2012). Determinants of e-government development: Some methodological issues. Journal of Management and Strategy, 3(3), 11-20.

34. Gil-García, J. R., \& Helbig, N.(2007). Exploring E-Government Benefits and Success Factors. In A. V. Anttiroiko \& M. Mälkiä (Eds.), Encyclopedia of Digital Government, 2, 803-811, Hershey: Idea Group Reference.

35. Hanna, N. K. (2010). Transforming Government and Building the Information Society: Challenges and Opportunities for the Developing World. New York: Springer.

36. Hesse, W., Muller, D., \& Ruß, A. (2008). Information, information systems, information society: Interpretations and implications. Poiesis Prax, 5, 159-183.

37. Hilbert, M. (2009). The maturing concept of e-democracy: From e-voting and online consultations to democratic value out of jumbled online chatter. Journal of Information Technology and Politics, 6(2), 87-11.

38. Hilty, L. M. (2008). Information technology and sustainability: Essays on the relationship between information technology and sustainable development. Norderstedt: Empa.

39. Hilty, L. M., \& Hercheui, M. D. (2010). ICT and Sustainable Development, What Kind of Information Society? In J. Berleur, M.D. Hercheui, \& L.M. Hilty (Eds.), What Kind of Information Society? Governance, Virtuality, Surveillance, Sustainability, Resilience, Introduction to the Conference Proceedings of 9th IFIP TC 9 International Conference, HCC9, and 1st IFIP TC 11 International Conference, CIP 2010 Held as Part of WCC 2010, (pp. 227-235). Brisbane: IFIP. 


\section{Issues in Information Systems \\ Volume 14, Issue 2, pp.87-100, 2013}

40. Hsu, C.C., \& Sandford, B. A. (2007). The Delphi Technique: Making Sense of Consensus. Practical Assessment Research \& Evaluation 12(10), Available: http://pareonline.net/getvn.asp?v=12\&n=10.

41. Ifinedo, P., \& Singh, M. (2011). Determinants of eGovernment maturity in the transition economies of Central and Eastern Europe. Electronic Journal of e-Government, 9(2), 166-182, Available: www.ejeg.com

42. Irani, Z \& Love, P. (2008). (Eds.), Evaluating Information Systems. Public and Private Sector. Oxford: Butterworth-Heinemann.

43. ISO/IEC 9126-1:2001Software engineering - Product quality - Part 1: Quality model

44. ISO/IEC 25010:2011 Systems and software engineering - Systems and software Quality Requirements and Evaluation (square) - System and software quality models

45. Kachwamba, M., \& Hussein, A. (2009). Determinants of e-government maturity: Do organizational specific factors matter?, Journal of US-China Public Administration, 6(7), 1-8.

46. Klaus, G., Grunert, K.G., \& Ellegaard, C. (1992). The Concept of Key Success Factors: Theory and Method. In M.J. Baker (Ed.), Perspectives on Marketing Management, (pp. 245-274). New York: Wiley.

47. Koohang, A. (2012). Active learning in e-learning: Advancing a systemic model. Issues in Information Systems, 13(1), 68-76.

48. Kovacic, Z. (2005). The impact of national culture on worldwide egovernment readiness, Informing Science, 8, 143-158.

49. Kunstelj, M., Jukic, T., \& Vintar, M. (2007). Analysing the demand side of e-government: What can we learn from Slovenian users? Electronic Government Lecture Notes in Computer Science, 4656, 305-317.

50. Layne, K., \& Lee, J. (2001). Developing fully functional e-government: a four stage model. Government Information Quarterly, 18(2), 122-136.

51. Leedy, P.D., \& Ormrod, J.E. (2005). Practical research: Planning and design. New Jersey: Prentice Hall.

52. Letch, N., \& Carroll, J. (2008). Excluded again: implications of integrated e-government systems for those at the margins. Information Technology \& People, 21(3), 283-299.

53. Linstone, H.A., \& Turoff, M. (2002). (Eds.), The Delphi method techniques and applications. MA: AddisonWesley.

54. Marche, S., \& McNiven, J.D. (2003). E-government and e-governance: the future isn't what it used to be. Canadian Journal of Administrative Science, 20(1), 74-86.

55. Michel, H. (2005). e-Administration, e-Government, e-Governance and the Learning City: A typology of Citizenship management using ICTs. The Electronic Journal of e-Government, 3(4), 213-218.

56. Moon, M.J., \& Norris, D.F. (2005). Does managerial orientation matter? The adoption of reinventing government and e-government at the municipal level. Information System Journal, 15, 43-60.

57. Mrayati, M. (2003). Towards sustainable economic growth in building the information society: Models for the role of engineers and scientists. The World Congress, Engineering \& Digital Divide, Tunisia: October 15-16, 2003

58. Nfuka, E. N., \& Rusu, L. (2011). The effect of critical success factors on IT governance performance. Industrial Management \& Data Systems, 111(9), 1418-1448.

59. Nurdin, N., Stockdale, R., \& Scheepers, H. (2012). Organizational Adaptation to Sustain Information Technology: The Case of E-Government in Developing Countries. Electronic Journal of e-Government, 10(1), 70-83, Available: www.ejeg.com

60. Oyomno, G.Z. (2004). Towards a framework for assessing the maturity of government capabilities for 'egovernment'. The Southern African Journal of Information and Comunication, 4, 77-97.

61. Pina V., Torres, L., \& Royo, S. (2009). E-government evolution in EU local governments: a comparative perspective. Online Information Review, 33(6), 1137-1168.

62. Pinter, R. (2008). (Ed.), Information society. From theory to political practice. Gondolat - Uj Mandatum: Budapeszt.

63. Prattipati, S. N. (2003). Adoption of e-Governance: Differences between countries in the use of online government services. Journal of American Academy of Business, 3(1/2), 386-401.

64. Raghupathi, W., \& Wu, S.J. (2011). The relationship between information and communication technologies and country governance: An exploratory study. Communications of the Association for Information Systems, 28(1), 181-198, Available: http://aisel.aisnet.org/cais/vol28/iss1/12.

65. Reddick, C.G. (2004). A two-stage model of e-government growth: Theories and empirical evidence for US sities, Government Information Quarterly, 21(1), 51-64.

66. Rivard. S., Aubert, B. A., \& Patry, M. (2004). Information technology and organizational transformation. Solving the management puzzle. New York: Elsevier. 


\section{Issues in Information Systems \\ Volume 14, Issue 2, pp.87-100, 2013}

67. Rockart, J. F. (1979). Chief executives define their own data needs. Harvard Business Review, 57(2), 81-93.

68. Serrano-Cinca, C., Rueda-Tomás, M., \& Portillo-Tarragona, P. (2009). Determinants of e-government extension. Online Information Review, 33(3), 476-498.

69. Siau, K., \& Long, Y. (2006). Using social development lenses to understand e-government development. Journal of Global Information Management, 14(1), 47-62.

70. Souter, D. (2004). The view from the summit: a report on the outcomes of the World Summit on the Information Society, Info, 6(1), 6-11.

71. Sultan, A., AlArfaj, K.A., \& AlKutbi, G.A. (2007). Analytic hierarchy process for the success of egovernment, Business Strategy Series, 13(6), 295-306.

72. Tapscott, D. \& Williams, A.D. (2006). Wikinomics: How Mass Collaboration Changes Everything. New York: Penguin Group.

73. The E-government Project. (2001).OECD. Available: http://www.oecd.org, 2010.

74. The user challenge benchmarking the supply of public services, (2007). 7th Measurement, September 2007, European Commission, Directorate General for Information Society and Media, Diegem.

75. Tolbert, C. J., \& Mossberger, K. (2006). The effects of e-government on trust and confidence in government. Public Administration Review, 66(3), 354- 369.

76. Wilson, C. (2010). Brainstorming. In C. Wilson (Ed.), User experience re-mastered: Your guide to getting the right design. (pp.107-134). Burlington: Morgan Kaufmann.

77. Yun, H, J and Opheim, C. (2010). Building on Success: The Diffusion of e-Government in the American States. Electronic Journal of e-Government, 8(1), 71-82, Available: www.ejeg.com

78. Zhao, Q. (2010). E-government evaluation of delivering public services to citizens among cities in the Yangtze River Delta. The International Information \& Library Review, 42, 208-211.

79. Zhao, F. (2011). Impact of national culture on e-government development: a global study, Internet Research, 21(3), 362-380.

80. Ziemba, E. (2013). Conceptual model of information technology support for prosumption. Proceedings of International Conference on Management, Leadership and Governance, 355-363, Bangkok: Bangkok University.

81. Ziemba, E. (2013). The holistic and systems approach to the sustainable information society. Journal for Computer Information Systems, (in print).

82. Ziemba, E., \& Olszak, C. M. (2012). Building a regional structure of an information society on the basis of eadministration. Issues in Informing Science and Information Technology, 9, 277-295.

83. Ziemba, E., \& Papaj, T. (2012). E-government application at the regional level in Poland - the case of SEKAP. Proceedings of the Federated Conference on Computer Science and Information Systems, Wrocław, Poland, 1075-1082.

84. Ziemba, E., \& Papaj, T. (2013). A pragmatic approach to the e-government maturity in Poland implementation and usage of SEKAP. Proceedings of European Conference on eGovernment, University of Isubria, Como, Italy, 355-363, (in print).

85. Ziemba., E., Papaj, T., \& Żelazny, R. (2013). New perspectives on information society: The maturity of research on a sustainable information society. Online Journal of Applied Knowledge Management, 1(1), 52-71.

86. Ziemba, E., \& Żelazny, R. (2013). A practical perspective on the developing information society - case studies. Online Journal of Applied Knowledge Management, 1(2), 25-43. 